\title{
Cyanide hydrolysis in a cyanide-degrading bacterium, Pseudomonas stutzeri AK61, by cyanidase
}

\author{
Atsushi Watanabe, Kazuyoshi Yano, Kazunori Ikebukuro \\ and Isao Karube
}

Research Center for Advanced Science and Technology, University of Tokyo, 4-6-1 Komaba, Meguro-ku, Tokyo 153, Japan
Author for correspondence: Isao Karube. Tel: +8133481 4471. Fax: +81334814581. e-mail: karube@bio.rcast.u-tokyo.ac.jp

\begin{abstract}
The cyanide-degrading bacterial strain AK61 was isolated from waste water at a metal-plating plant. The isolated strain was characterized by Gram-staining, quinone analysis, fatty acid profile and the API 20NE identification system, and identified as Pseudomonas stutzeri. Whole cells were able to degrade cyanide rapidly in a $1 \mathrm{mM}$ solution containing no organic substances, and produced ammonia as a product. The induction of the cyanide-degrading activity of $P$. stutzeri AK61 did not depend on the presence of cyanide in the culture medium during growth. The cyanide-degrading enzyme was purified approximately 49-fold from a cell extract of $P$. stutzeri AK61. The enzyme had a $K_{\mathrm{m}}$ of $1.7 \mathrm{mM}$ for cyanide and a specific activity of $54.6 \mu \mathrm{mol}$ ammonia produced $\mathrm{min}^{-1}$. The activity of the enzyme was optimal at $30^{\circ} \mathrm{C}$ and pH 7.5. The results of SDS-PAGE, gel-filtration chromatography and $\mathbf{N H}_{2}$-terminal amino acid sequence analysis of the enzyme indicated that the functional enzyme was an aggregated protein consisting of a $38 \mathrm{kDa}$ polypeptide. Like cyanidase (cyanide dihydratase), it was shown that the enzyme catalysed the hydrolysis of cyanide to ammonia and formate.
\end{abstract}

Keywords: cyanide degradation, hydrolysis, cyanidase

\section{INTRODUCTION}

Cyanide is highly toxic to living organisms because it inactivates the respiration system by tightly binding to cytochrome $c$ oxidase (Solomonson \& Spehar, 1981). Despite the toxicity of cyanide, large amounts of it are used in the metal-plating, pharmaceutical and agricultural-chemical industries. Waste water containing cyanide from these industries must be treated so that it contains a low level $\left(<1 \mathrm{mg} \mathrm{l}^{-1}\right)$ of cyanide before being released into the environment (Raybuck, 1992). Currently, cyanide in waste water is removed by chemical methods such as alkaline chlorination, ozonization and wet-air oxidation (Raybuck, 1992). These methods are expensive and require the use of hazardous reagents such as chlorine and sodium hypochlorite. Biological treatment of cyanide may be cheaper and more environmentally acceptable than chemical methods (Dubey \& Holmes, 1995).

To develop the biological treatment of cyanide, screening of cyanide-degrading micro-organisms has been carried out. Some biological pathways have been suggested for the degradation or detoxification of cyanide in bacteria and fungi (Knowles \& Bunch, 1986; Raybuck, 1992; Dubey \& Holmes, 1995). Pseudomonas fluorescens NCIMB 11764 has been shown to grow in a medium containing cyanide as the sole nitrogen source (Harris \& Knowles, 1983). P. fluorescens NCIMB 11764 converts cyanide to ammonia and carbon dioxide. This reaction may proceed by means of $\mathrm{NAD}(\mathrm{P}) \mathrm{H}$-dependent oxygenase and cyanase (Dorr \& Knowles, 1989). A Pseudomonas species which degraded cyanide by another pathway was isolated from the activated sludge at a coke plant (White et al., 1988). Although the cyanide-degrading enzyme was not purified, it was shown that the strain degraded cyanide to ammonia and formate under both aerobic and anaerobic conditions. Recently, Alcaligenes xylosoxidans subsp. denitrificans DF3 (Ingvorsen et al., 1991) and Bacillus pumilus C1 (Meyers et al., 1991) were also shown to degrade cyanide by the same pathway as the pseudomonad. These strains have been reported to degrade cyanide by cyanidase (cyanide dihydratase), which catalyses the hydrolysis of cyanide to ammonia and formate (Ingvorsen et al., 1991; Meyers et al., 1993). Some phytopathogenic fungi, 
including Gloeocercospora sorghi (Fry \& Munch, 1975; Wang et al., 1992), Fusarium lateritium (Cluness et al., 1993) and Stemphylium loti (Fry \& Millar, 1972), have also been reported to degrade cyanide. Cyanide hydratases (EC 4.2.1.66) catalysing the hydrolysis of cyanide to formamide have been purified from G. sorghi and F. lateritium, and subsequently characterized.

In this study, we report the isolation of a cyanidedegrading bacterium from the waste water of a metal-plating plant. In addition, purification and characterization of a cyanide-degrading enzyme from the strain are described.

\section{METHODS}

Isolation of the cyanide-degrading strain. The cyanidedegrading micro-organism was isolated from the waste water of a metal-plating plant by cultivation in an isolation medium containing $1 \mathrm{mM} \mathrm{KCN}$. The isolation medium contained the following ingredients per litre distilled water: $1 \mathrm{~g}$ $\mathrm{K}_{2} \mathrm{HPO}_{4} .2 \mathrm{H}_{2} \mathrm{O}, 0.2 \mathrm{~g} \mathrm{MgSO}_{4} .7 \mathrm{H}_{2} \mathrm{O}, 0.01 \mathrm{~g} \mathrm{CaCl}, 0.01 \mathrm{~g}$

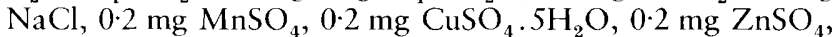
2 g glucose, $1 \mathrm{~g}$ tryptone. The $\mathrm{pH}$ of the medium was adjusted to 7.6 using $\mathrm{HCl}$. KCN solution, which was sterilized using a $0 \cdot 2 \mu \mathrm{m}$ pore filter, was added to the medium before inoculation. The isolation medium in a shake flask was inoculated with the waste water and incubated at $30^{\circ} \mathrm{C}$ for $48 \mathrm{~h}$ with shaking. The grown culture was serially diluted and plated onto TYG agar $\left(5 \mathrm{~g}\right.$ tryptone $\mathrm{l}^{-1}, 5 \mathrm{~g}$ yeast extract $\mathrm{l}^{-1}$, $1 \mathrm{~g}$ glucose $\mathrm{l}^{-1}, 1 \mathrm{~g} \mathrm{~K}_{2} \mathrm{HPO}_{4} \mathrm{l}^{-1}, 20 \mathrm{~g}_{\text {agar } \mathrm{l}^{-1}}$ ). After $24 \mathrm{~h}$ incubation at $30^{\circ} \mathrm{C}$, the isolates obtained by restreaking colonies onto TYG agar were inoculated into isolation medium containing $1 \mathrm{mM} \mathrm{KCN}$ and incubated at $30^{\circ} \mathrm{C}$ for $24 \mathrm{~h}$. To determine cyanide-degrading activity of the isolates, the concentration of residual cyanide in each culture medium was assayed by the method of Lambert et al. (1975).

The cyanide-degrading bacterium was characterized by Gramstaining, quinone analysis, fatty acid profile and the API $20 \mathrm{NE}$ identification system (Bio Mérieux). Gram-staining was performed according to Gerhardt (1981). Fatty acids were analysed according to the method reported previously (Ikemoto et al., 1978a, b; Oyaizu \& Komagata, 1981) and the quinone system was determined by the method of Yamada $e t$ al. (1969). The API 20NE identification system was inoculated and interpreted according to the manufacturer's instructions.

Assay of cyanide-degrading activity of whole cells. The isolated strain was grown in isolation medium with or without $1 \mathrm{mM} \mathrm{KCN}$ for $24 \mathrm{~h}$ and harvested in the exponential growth phase by centrifugation at $4000 \mathrm{~g}$ for $15 \mathrm{~min}$. The pellet was washed twice in $50 \mathrm{mM}$ phosphate buffer $(\mathrm{pH} 7.6)$ and resuspended in the same buffer. A suspension of washed cells was diluted in phosphate buffer to produce a solution with an $\mathrm{OD}_{600}$ of 1 (DU 7400 spectrophotometer, Beckman). KCN as a substrate was added to a final concentration of $1 \mathrm{mM}$ in the suspension and the mixture was incubated at $30^{\circ} \mathrm{C}$. Samples were removed from the reaction mixture at appropriate intervals and the reaction was stopped by the addition of $2 \mathrm{vol}$. $1 \mathrm{M} \mathrm{NaOH}$. The samples were then centrifuged at $10000 \mathrm{~g}$ and concentrations of cyanide and ammonia in the supernatants were assayed colorimetrically using the methods of Lambert et al. (1975) and Fawcett \& Scott (1960), respectively.

Enzyme purification. The isolated strain was grown using 31 of medium. The cells were harvested and washed as described above. The washed cell suspension was disrupted by sonication for $10 \mathrm{~min}$ on ice and centrifuged at $10000 \mathrm{~g}$ for $15 \mathrm{~min}$ at $4{ }^{\circ} \mathrm{C}$. The supernatant was used for purification of the cyanide-degrading enzyme as a cell extract. All purification steps were carried out at $4{ }^{\circ} \mathrm{C}$. The cell extract was brought to $35 \%$ saturation with $\left(\mathrm{NH}_{4}\right)_{2} \mathrm{SO}_{4}$ by the addition of crystals. The supernatant was recovered by centrifugation and brought to $45 \%$ saturation by further addition of $\left(\mathrm{NH}_{4}\right)_{2} \mathrm{SO}_{4}$. The pellet was recovered and dissolved in $50 \mathrm{mM}$ phosphate buffer ( $\mathrm{pH} 7 \cdot 6)$. This solution was applied to a DEAM column (Yamazen) previously equilibrated with $0.4 \mathrm{M} \mathrm{NaCl}$ in phosphate buffer. Proteins bound to the column were eluted with $0.5 \mathrm{M} \mathrm{NaCl}$. An equal volume of $1.8 \mathrm{M}\left(\mathrm{NH}_{4}\right)_{2} \mathrm{SO}_{4}$ in phosphate buffer was added to the eluted proteins, and the mixture applied to a phenyl-Toyopearl 650 column (Tosoh) equilibrated with $0.9 \mathrm{M}\left(\mathrm{NH}_{4}\right)_{2} \mathrm{SO}_{4}$ in phosphate buffer. Fractions eluted with decreasing $\left(\mathrm{NH}_{4}\right)_{2} \mathrm{SO}_{4}$ concentrations of $0.54-0 \mathrm{M}$ were collected. Two volumes of $1 \mathrm{mM}$ phosphate buffer $(\mathrm{pH} 7.0)$ were added to the eluted proteins. These proteins were applied to a DEAE-Toyopearl 650 column (Tosoh) equilibrated with $0.15 \mathrm{M} \mathrm{NaCl}$ in $1 \mathrm{mM}$ phosphate buffer $(\mathrm{pH} 7 \cdot 0)$. The proteins were eluted using a $\mathrm{NaCl}$ gradient from $0 \cdot 15$ to $1 \mathrm{M}$. All active fractions were applied to a Macro-Prep ceramic hydroxyapatite column (Bio-Rad) equilibrated with $0.3 \mathrm{M} \mathrm{NaCl}$ in $1 \mathrm{mM}$ phosphate buffer $(\mathrm{pH} 7 \cdot 0)$ and eluted with a phosphate gradient of $1-250 \mathrm{mM}$. The active fractions were referred to as the purified enzyme. For gel-filtration chromatography, the purified enzyme was applied to a TSK-GEL G2000SWXL column (Tosoh), which had an exclusion limit of $100 \mathrm{kDa}$, and eluted with $50 \mathrm{mM}$ phosphate buffer ( $\mathrm{pH} 7 \cdot 6$ ) containing $0.3 \mathrm{M} \mathrm{NaCl}$.

Assay of enzyme activity. Enzymic activity was assayed in $1.4 \mathrm{ml} 50 \mathrm{mM}$ phosphate buffer $(\mathrm{pH} 7.5)$ containing $10 \mathrm{mM}$ $\mathrm{KCN}$ as the substrate. The reaction was carried out at $30^{\circ} \mathrm{C}$ for $3-10 \mathrm{~min}$. The amount of ammonia produced in the reaction mixtures was estimated using the method mentioned above. The amounts of protein were estimated using the method of Bradford (1976) with bovine serum albumin as the standard. One unit of the enzyme is defined as the amount needed to catalyse the formation of $1 \mu \mathrm{mol}$ ammonia from cyanide $\min ^{-1}$ under the above conditions.

Other assays. The production of formate via the degradation of cyanide by the purified enzyme was assayed. The reaction was carried out in $50 \mathrm{mM}$ phosphate buffer ( $\mathrm{pH} 7 \cdot 6$ ) with an initial concentration of $0 \cdot 1-1 \mathrm{mM}$ cyanide at $30^{\circ} \mathrm{C}$. After degradation of cyanide in the reaction mixtures, concentrations of formate were determined. Formate was colorimetrically estimated by the reduction of $\mathrm{NAD}^{+}$with formate dehydrogenase (Boehringer Mannheim) as described by Quayle (1966).

SDSPAGE. SDS-PAGE was performed on $12 \%$ polyacrylamide gels according to the method of Laemmli (1970). Proteins were stained with $0 \cdot 2 \%$ Coomassie brilliant blue R250 in $50 \%$ ethanol/10\% acetic acid. The molecular mass of the enzyme polypeptide was determined by comparison with the mobilities of standard proteins.

\section{RESULTS AND DISCUSSION}

\section{Isolation and characteristics of $P$. stutzeri AK61}

Several bacterial strains were isolated from the waste water of a metal plating plant with the isolation medium containing $1 \mathrm{mM} \mathrm{KCN}$. One of them, designated AK61, exhibited cyanide-degrading activity. Strain AK61 was a 


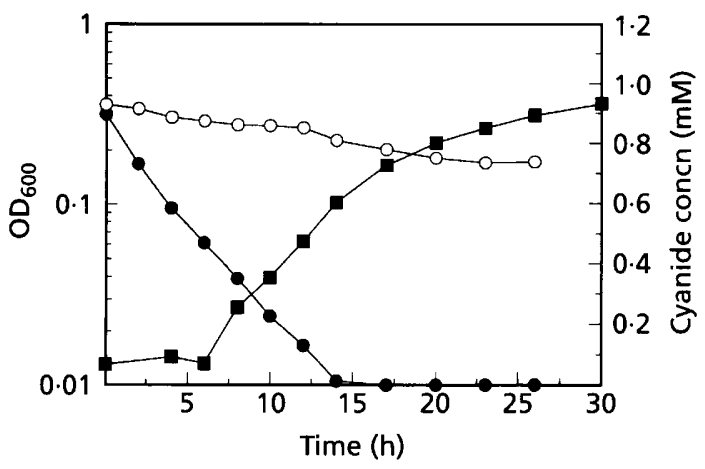

Fig. 1. Growth of P. stutzeri AK61 in isolation medium containing cyanide. The culture was incubated at $30^{\circ} \mathrm{C}$ with shaking. The initial concentration of cyanide was $1 \mathrm{mM}$. $\square$, $\mathrm{OD}_{600} ; O$, cyanide concentration in growth medium; $\mathrm{O}$, cyanide concentration in uninoculated control medium.

Gram-negative, rod-shaped bacterium that was not able to grow under anaerobic conditions. Analysis of the quinone system revealed the occurrence of a ubiquinone with nine isoprenoic units in the side chain (Q-9). The profile of cellular fatty acids obtained from strain AK61 showed high amounts of octadecanoic acid (18:0), hexadecanoic acid $(16: 0)$ and hexadecenoic acid $(16: 1)$ and the presence of $3-\mathrm{OH}$-decanoic acid $(10: 0-3-\mathrm{OH})$ and $3-\mathrm{OH}$-dodecanoic acid $(12: 0-3-\mathrm{OH})$ (data not shown). The fatty acid profile and the quinone system demonstrate that strain AK61 belongs to the genus Pseudomonas (Yokota et al., 1992; Oyaizu \& Komagata, 1983; Collins \& Jones, 1981). The detection of 3-hydroxy fatty acids has been reported to be especially significant for the classification of Pseudomonas species (Oyaizu \& Komagata, 1983). Investigation with the commercially available API 20NE identification system for strain AK61 resulted in an identification as Pseudomonas stutzeri with a probability of $94.2 \%$. The DNA base composition (GC content) of strain AK61 ranged from 62 to $63 \mathrm{~mol} \%$, which matched with that of $P$. stutzeri (Krieg \& Holt, 1984).

\section{Degradation of cyanide by P. stutzeri AK61}

A typical time course of cultivation of $P$. stutzeri AK61 in the isolation medium containing $1 \mathrm{mM} \mathrm{KCN}$ is shown in Fig. 1. An initial lag period of about $6 \mathrm{~h}$ was observed after inoculation, during which time cyanide in the medium was degraded. After this period, growth commenced. Within $17 \mathrm{~h}$, all free cyanide in the solution was degraded. The final $\mathrm{OD}_{600}$ after $30 \mathrm{~h}$ incubation was approximately 0.4 .

A degradation profile of cyanide by the washed cells was assayed in phosphate buffer containing $1 \mathrm{mM} \mathrm{KCN}$ (Fig. 2). Rapid removal of cyanide and the simultaneous accumulation of ammonia was observed in the reaction mixtures (data not shown). The final molar yield of

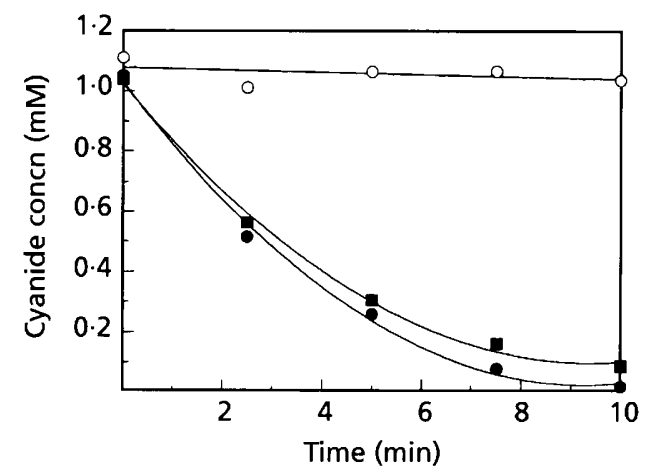

Fig. 2. Degradation of cyanide by whole cells previously grown in the isolation medium with $1 \mathrm{mM} \mathrm{KCN} \mathrm{(O)} \mathrm{and} \mathrm{without}$ cyanide ( $\boldsymbol{\square}$ ). The reaction was carried out in $50 \mathrm{mM}$ phosphate buffer $(\mathrm{pH} 7.6)$ containing $1 \mathrm{mM} \mathrm{KCN}$ at $30^{\circ} \mathrm{C}$. $\mathrm{O}$, Cyanide concentration in uninoculated control medium.

ammonia was approximately $73 \%$. Some bacterial strains which are able to degrade cyanide and generate ammonia have been isolated. P. fluorescens NCIMB 11746 converted cyanide to ammonia and carbon dioxide (Dorr \& Knowles, 1989). In addition, Pseudomonas sp. (White et al., 1988), A. xylosoxidans subsp. denitrificans DF3 (Ingvorsen et al., 1991) and B. pumilus C1 (Meyers et al., 1991) were reported to convert cyanide to ammonia and formate. The cyanide-degrading activity of $P$. fluorescens NCIMB 11746 and A. xylosoxidans subsp. denitrificans DF3 was induced by cyanide during growth. On the other hand, induction of the cyanide-degrading activity of $B$. pumilus $\mathrm{C} 1$ was inhibited by addition of cyanide into the medium (Meyers et al., 1991). The cyanide-degrading activity of B. pumilus $\mathrm{C} 1$ was observed in only late-exponential- or early-stationary-phase cells cultured without cyanide. In contrast, the cyanide-degrading activity of $P$. stutzeri AK61 was observed whether it was cultured in cyanidecontaining media or not (Fig. 2). The degradation profile of cyanide by the cells cultured without cyanide was similar to that of the cells cultured with cyanide. These results suggest that the biosynthesis of the cyanidedegrading enzyme by P. stutzeri AK61 is independent of the presence of cyanide during culture. This property of $P$. stutzeri AK61 may be useful for applying this strain to biological treatment of cyanide and preparing the cyanide-degrading enzyme, because $P$. stutzeri AK61 does not require cyanide to produce the cyanidedegrading activity and the induction is not inhibited by cyanide.

\section{Purification of cyanide-degrading enzyme}

A cell extract of $P$. stutzeri AK61 prepared from 3 l of culture in isolation medium without cyanide showed an initial specific activity of $1 \cdot 11$ units $(\mathrm{mg} \text { protein })^{-1}$. The cyanide-degrading enzyme was purified by salting-out and column chromatography. The results of a typical 
Table 1. Purification of cyanide-degrading enzyme from P. stutzeri AK61

Reactions were carried out in $1.4 \mathrm{ml} 50 \mathrm{mM}$ phosphate buffer ( $\mathrm{pH} 7.5)$ containing $10 \mathrm{mM} \mathrm{KCN}$ for $5 \min$ at $30^{\circ} \mathrm{C}$.

\begin{tabular}{|lccccc|}
\hline Fraction & $\begin{array}{c}\text { Total } \\
\text { protein } \\
(\mathbf{m g})\end{array}$ & $\begin{array}{c}\text { Total } \\
\text { activity } \\
(\text { units })^{*}\end{array}$ & $\begin{array}{c}\text { Specific } \\
\text { activity [units } \\
\left.(\text { mg protein })^{-1}\right]\end{array}$ & Yield (\%) & $\begin{array}{c}\text { Purification } \\
\text { (-fold) }\end{array}$ \\
\hline Cell extract & $163 \cdot 5$ & 182 & $1 \cdot 11$ & 100 & $1 \cdot 0$ \\
DEAM & $1 \cdot 41$ & $47 \cdot 2$ & $33 \cdot 5$ & $26 \cdot 0$ & $30 \cdot 1$ \\
DEAE-Toyopearl 650 & 0.78 & $34 \cdot 5$ & $44 \cdot 2$ & $18 \cdot 9$ & $39 \cdot 7$ \\
Hydroxyapatite & 0.43 & $23 \cdot 3$ & $54 \cdot 6$ & $12 \cdot 8$ & $49 \cdot 0$ \\
\hline
\end{tabular}

"One unit of the enzyme was defined as the amount needed to catalyse the formation of $1 \mu \mathrm{mol}$ ammonia from cyanide $\mathrm{min}^{-1}$.

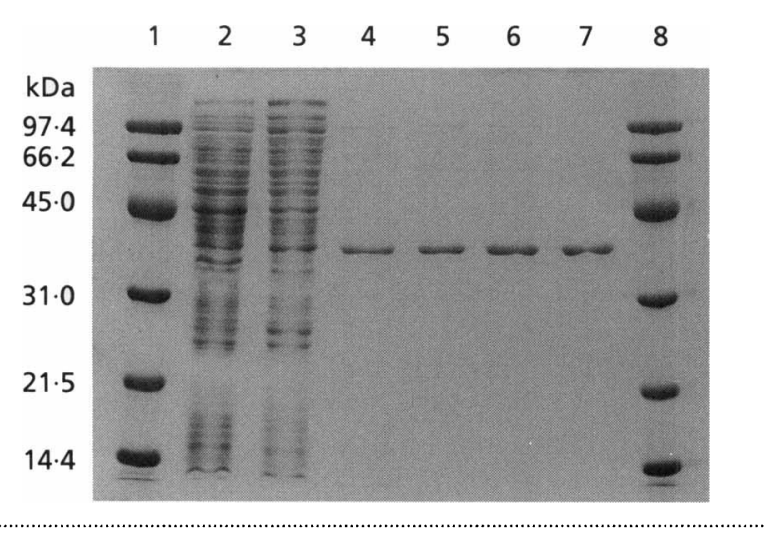

Fig. 3. SDS-PAGE of steps during the purification of the cyanide-degrading enzyme from $P$. stutzeri AK61. Lanes: 1 and 8, molecular mass standards (rabbit muscle phosphorylase $b$, BSA, hen egg-white ovalbumin, bovine carbonic anhydrase, soybean trypsin inhibitor and hen egg-white lysozyme); 2 , cell extract; 3, salt-out; 4, DEAM eluate; 5, phenyl-Toyopearl eluate; 6 , DEAE-Toyopearl eluate; 7 , hydroxyapatite eluate.

purification are shown in Table 1 . The cyanide-degrading enzyme was purified 49 -fold using this procedure with an overall yield of $12.8 \%$. The purified enzyme had a specific activity of 54.6 unit (mg protein $)^{-1}$. The enzyme responsible for the activity had a molecular mass of $>100 \mathrm{kDa}$ based on gel-filtration chromatography, but produced one major band at $38 \mathrm{kDa}$ when analysed by SDS-PAGE (Fig. 3). When the $\mathrm{NH}_{2}$-terminal amino acid sequence of the purified enzyme was determined by automated Edman degradation, only one sequence was found (Fig. 4). These results suggest that the functional enzyme is an aggregated protein that consists of a $38 \mathrm{kDa}$ polypeptide subunit. The $\mathrm{NH}_{2}{ }^{-}$ terminal amino acid sequence of the purified enzyme had remarkable homology to those of cyanidase from $A$. xylosoxidans subsp. denitrificans DF3 (Ingvorsen et al., 1991) and cyanide dihydratase from B. pumilus C1 (Meyers et al., 1993). It showed a match between 16 of 25 amino acids for the $\mathrm{NH}_{2}$-terminal amino acid

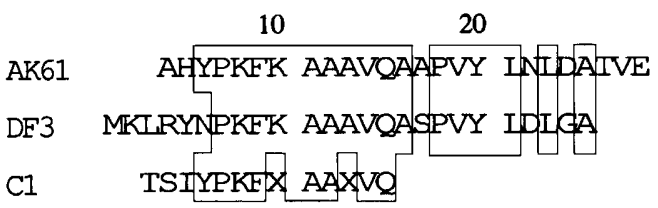

Fig. 4. $\mathrm{NH}_{2}$-terminal amino acid sequence of the cyanidedegrading enzyme from $P$. stutzeri AK61 (AK61) and comparison with those of cyanidase from $A$. xylosoxidans subsp. denitrificans DF3 (DF3) and cyanide dihydratase from $B$. pumilus C1 (C1). Identical residues are enclosed by boxes.

sequence of cyanidase from A. xylosoxidans subsp. denitrificans DF3 (Fig. 4).

\section{Kinetic studies}

The initial velocity of cyanide degradation by the purified enzyme was investigated over a substrate concentration range of $0 \cdot 6-10 \mathrm{mM}$. A Lineweaver-Burk plot showed a linear response over this concentration range (data not shown). A Michaelis-Menten constant $\left(K_{\mathrm{m}}\right)$ of $1.7 \mathrm{mM}$ was determined for cyanide. In order to study the effect of temperature and $\mathrm{pH}$ on the purified enzyme activity, it was assayed over a temperature range of $15-40^{\circ} \mathrm{C}$ and a $\mathrm{pH}$ range of $6-10$. The optimum temperature for the enzyme under our assay conditions was $30^{\circ} \mathrm{C}$ (data not shown), above which the activity rapidly decreased. The optimum $\mathrm{pH}$ for the enzymic activity was 7.5 (data not shown), above which the activity decreased; no activity was observed at $\mathrm{pH} 10$.

The effects on enzyme activity of the following metal ions were investigated: $\mathrm{K}^{+}, \mathrm{Na}^{+}, \mathrm{Fe}^{3+}, \mathrm{Ca}^{2+}, \mathrm{Mg}^{2+}$, $\mathrm{Zn}^{2+}, \mathrm{Mn}^{2+}, \mathrm{Ni}^{2+}, \mathrm{Hg}^{2+}, \mathrm{Cr}^{3+}, \mathrm{Co}^{2+}$. The activity was strongly inhibited by addition of $\mathrm{Hg}^{2+}$ at a concentration of $0.1 \mathrm{mM}$; the relative activity was $3 \cdot 6 \%$. This suggests the possible presence of thiol groups at the catalytic site of the enzyme. The addition of the other cations to the reaction buffer did not affect the activity of the enzyme. 


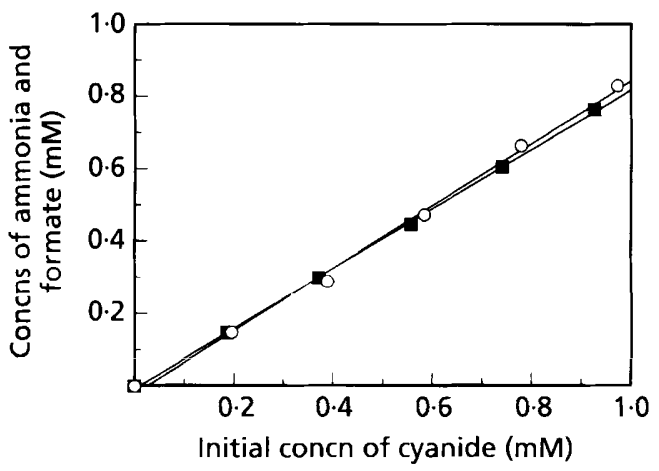

Fig. 5. Production of ammonia and formate after degradation of cyanide. The reactions were carried out in $50 \mathrm{mM}$ phosphate buffer ( $\mathrm{pH} 7.5$ ) with various concentrations of cyanide at $30^{\circ} \mathrm{C}$ for $30 \mathrm{~min}$. After the cyanide was degraded, the concentrations of formate $(O)$ and ammonia $(\boldsymbol{E})$ in the reaction mixtures were assayed.

\section{Relative products}

As a result of cyanide degradation by whole cells, ammonia was produced in the reaction mixture. The purified enzyme was able to degrade cyanide in a phosphate buffer without a co-enzyme. In addition, the $\mathrm{NH}_{2}$-terminal amino acid sequence of the purified enzyme shows remarkable homology to that of cyanidase from A. xylosoxidans subsp. denitrificans DF3 (Ingvorsen et al., 1991). It is possible that the enzyme purified from $P$. stutzeri AK61 catalyses the same reaction as cyanidase (cyanide dihydratase), which catalyses the hydrolysis of cyanide to ammonia and formate (Ingvorsen et al., 1991; Meyers et al., 1993). To demonstrate that, like cyanidase, the purified enzyme converts cyanide to formate and ammonia, production of formate was assayed using formate-dehydrogenasecatalysed reduction of $\mathrm{NAD}^{+}$. Because cyanide forms a complex, which has an absorption maximum at approximately $320 \mathrm{~nm}$, with $\mathrm{NAD}^{+}$(Imai \& Suzuki, 1970), ammonia and formate concentrations were estimated after the cyanide in the reaction mixtures was completely degraded. The purified enzyme was added to phosphate buffer solutions containing several different concentrations of cyanide, and the final concentrations of formate and ammonia in the reaction mixtures were estimated. The final concentrations of formate and ammonia increased linearly, and the amounts of the products were equivalent to approximately $80 \%$ of the initial concentration of cyanide (Fig. 5). This result showed that the enzyme from $P$. stutzeri AK61 catalysed the hydrolysis of cyanide like cyanidase and that $P$. stutzeri AK61 degrades cyanide by the same pathway as A. xylosoxidans subsp. denitrificans DF3 and B. pumilus C1.

Cyanidase from P. stutzeri AK61 has similar properties to cyanidase from A. xylosoxidans subsp. denitrificans DF3 (Ingvorsen et al., 1991) and cyanide dihydratase from B. pumilus C1 (Meyers et al., 1991). These enzymes had molecular masses of over $100 \mathrm{kDa}$ based on gel- filtration chromatography, and the polypeptide chains of the enzymes had molecular masses of approximately $38 \mathrm{kDa}$ as shown by SDS-PAGE. In addition, the enzymes had a $K_{\mathrm{m}}$ of approximately $2 \mathrm{mM}$ for cyanide and the $\mathrm{NH}_{2}$-terminal amino acid sequence of cyanidase from $P$. stutzeri AK61 shows a remarkable homology to that of cyanidase from A. xylosoxidans subsp. denitrificans DF3 (Ingvorsen et al., 1991). These enzymes, however, also show a number of different properties. The three enzymes show different optimum temperatures $\left(26^{\circ} \mathrm{C}\right.$ for cyanidase from $A$. xylosoxidans subsp. denitrificans DF $3,37^{\circ} \mathrm{C}$ for cyanide dihydratase from $B$. pumilus $\mathrm{C} 1$ and $30^{\circ} \mathrm{C}$ for the purified enzyme in this paper). The activity of cyanide dihydratase from $B$. pumilus $\mathrm{C} 1$ was significantly enhanced by addition of $\mathrm{Cr}^{3+}$ at a concentration of 5-500 $\mu \mathrm{M}$ (Meyers et al., 1991). However, the addition of $100 \mu \mathrm{M} \mathrm{Cr}^{3+}$ did not affect the activity of cyanidase from P. stutzeri AK61. The results of SDS-PAGE, gel-filtration chromatography and the $\mathrm{NH}_{2}$-terminal amino acid sequence of cyanidase from $P$. stutzeri AK61 showed that this enzyme consists of one kind of polypeptide. In contrast, cyanidase (cyanide dihydratase) from $A$. xylosoxidans subsp. denitrificans DF3 (Ingvorsen et al., 1991) and B. pumilus C1 (Meyers et al., 1993) consisted of two and three kinds of polypeptide chains, respectively. Proteins which consist of one polypeptide are suitable for gene cloning and for expression in an active form.

\section{ACKNOWLEDGEMENTS}

We thank Associate Professor Akira Yokota for suggestions during the identification of the isolated bacterium.

\section{REFERENCES}

Bradford, M. (1976). A rapid and sensitive method for the quantitation of microgram quantities of protein utilizing the principle of protein-dye binding. Anal Biochem 72, 248-254.

Cluness, M. J., Turner, P. D., Clements, E., Brown, D. T. \& O'Reilly, C. (1993). Purification and properties of cyanide hydratase from Fusarium lateritium and analysis of the corresponding chy 1 gene. J Gen Microbiol 139, 1807-1815.

Collins, M. D. \& Jones, D. (1981). Distribution of isoprenoid quinone structural types in bacteria and their taxonomic implications. Microbiol Rev 45, 316-354.

Dorr, P. K. \& Knowles, C. J. (1989). Cyanide oxygenase and cyanase activities of Pseudomonas fluorescens NCIMB 11764. FEMS Microbiol Lett 60, 289-294.

Dubey, S. K. \& Holmes, D. S. (1995). Biological cyanide destruction mediated by microorganisms. World J Microbiol Biotechnol 11, 257-265.

Fawcett, J. K. \& Scott, J. E. (1960). A rapid and precise method for the determination of urea. J Clin Pathol 13, 156-159.

Fry, W. E. \& Millar, R. L. (1972). Cyanide degradation by an enzyme from Stemphylium loti. Arch Biochem Biophys 151, $468-474$.

Fry, W. E. \& Munch, D. C. (1975). Hydrogen cyanide detoxification by Gloeocercospora sorghi. Physiol Plant Pathol 7, 23-33.

Gerhardt, P. (1981). Manual of Methods for General Bacteriology, 4th edn. Washington, DC: American Society for Microbiology.

Harris, R. \& Knowles, C. J. (1983). Isolation and growth of a 
Pseudomonas species that utilizes cyanide as a source of nitrogen. J Gen Microbiol 129, 1005-1011.

Ikemoto, S., Kuraishi, H., Komagata, K., Azuma, R., Sato, T. \& Murooka, K. (1978a). Cellular fatty acid composition in Pseudomonas species. J Gen Appl Microbiol 24, 199-213.

Ikemoto, S., Katoh, K. \& Komagata, K. (1978b). Cellular fatty acid composition in methanol-utilizing bacteria. J Gen Appl Microbiol 24, 41-49.

Imai, T. \& Suzuki, S. (1970). Isolation and identification of pyridine nucleotides. Protein Nucleic Acid Enzyme 15, 162-173.

Ingvorsen, K., Hojer-Pedersen, B. \& Godtfredsen, S. E. (1991). Novel cyanide-hydrolyzing enzyme from Alcaligenes xylosoxidans subsp. denitrificans. Appl Environ Microbiol 57, 1783-1789.

Krieg, N. R. \& Holt, J. G. (1984). Bergey's Manual of Systematic Bacteriology, vol. 1. Baltimore: Williams \& Wilkins.

Knowles, C. J. \& Bunch, A. W. (1986). Microbial cyanide metabolism. Adv Microb Physiol 27, 73-111.

Laemmli, U. K. (1970). Cleavage of structural protein during the assembly of the head of bacteriophage T4. Nature 227, 680-685.

Lambert, J. L., Ramasamy, J. \& Paukstells, J. V. (1975). Stable reagents for the colorimetric determination of cyanide by modified König reactions. Anal Chem 47, 916-918.

Meyers, P. R., Gokool, P., Rawlings, D. E. \& Woods, D. R. (1991). An efficient cyanide-degrading Bacillus pumilus strain. $J$ Gen Microbiol 137, 1397-1400.

Meyers, P. R., Rawlings, D. E., Woods, D. R. \& Lindsey, G. G. (1993). Isolation and characterization of a cyanide dihydratase from Bacillus pumilus C1. J Bacteriol 175, 6105-6112.

Oyaizu, H. \& Komagata, K. (1981). Chemotaxonomic and phenotypic characterization of the strains of species in the Flavobacterium-Cytophaga complex. J Gen Appl Microbiol 27, 57-107.
Oyaizu, H. \& Komagata, K. (1983). Grouping of Pseudomonas species on the basis of cellular fatty acid composition and the quinone system with special reference to the existence of 3 hydroxy fatty acid. J Gen Appl Microbiol 29, 17-40.

Quayle, J. R. (1966). Dehydrogenases and oxidases: formate dehydrogenase. Methods Enzymol 9, 360-364.

Raybuck, S. A. (1992). Microbes and microbial enzymes for cyanide degradation. Biodegradation 3, 3-18.

Solomonson, L. P. \& Spehar, A. M. (1981). Cyanide as a metabolic inhibitor. In Cyanide in Biology, pp. 11-28. Edited by $\mathrm{B}$. Vennesland, E. E. Conn, C. J. Knowles, J. Westley \& F. Wissing. London: Academic Press.

Wang, P., Matthews, D. E. \& VanEtten, H. D. (1992). Purification and characterization of cyanide hydratase from phytopathogenic fungus Gloeocercospora sorghi. Arch Biochem Biophys 298, 569-575.

White, J. M., Jones, D. D., Huang, D. \& Gauthier, J. J. (1988). Conversion of cyanide to formate and ammonia by a pseudomonad obtained from industrial waste water. J Ind Microbiol 3, 263-272.

Yamada, Y., Aida, K. \& Uemura, T. (1969). Enzymatic studies on the oxidation of sugar and sugar alcohol. V. Ubiquinone of acetic acid bacteria and its relation to classification of genera Gluconobacter and Acetobacter especially of the so-called intermediate strains. J Gen Appl Microbiol 15, 181-196.

Yokota, A., Akagawa-Matsushita, M., Hiraishi, A., Katayama, Y., Urakami, T. \& Yamasato, K. (1992). Distribution of quinone systems in microorganisms: gram-negative Eubacteria. Bull Jpn Fed Cul Collect 8, 136-171.

Received 28 October 1997; revised 2 February 1998; accepted 4 February 1998. 